Anne Holt har doktorgrad i fysikk fra Universitetet i Oslo, og jobber nå som førsteamanuensis ved Høgskolen i Hedmark (HH).

Per Ivar Kvammen har hovedfag i biologi og er førsteamanuensis i realfagdidaktikk ved HH.

Anne Bergliot $\varnothing$ yehaug har hovedfag i biologi, er høgskolelektor ved HH og har nylig startet på et PhD-studium i naturfagdidaktikk innenfor prosjektet "Bedre læringsstrategier i realfag".

Mats Molberg og Bjarte Rom har doktorgrad i matematikk og er begge førsteamanuenser ved HH.

Forfatternes felles forskningsinteresse er skolerettet forskning innenfor realfagdidaktikk.

ANNE HOLT

Anne.holt@hihm.no

ANNE BERGLJOT $\varnothing$ YEHAUG

Anne.oyehaug@hihm.no
PER IVAR KVAMMEN

Per.kvammen@hihm.no

BJARTE ROM

Bjarte.rom@hihm.no

Alle er tilknyttet Avdeling for lærerutdanning og naturvitenskap, Høgskolen i Hedmark

\title{
Bedre læringsstrategier i realfag
}

\section{Innledning}

Prosjektet "Bedre læringsstrategier i realfag", et samarbeidprosjekt mellom Nes kommune i Akershus og Høgskolen i Hedmark, startet som et skole-foreldreinitiativ for å oppnå bedre læringsresultater og utjevne sosiale forskjeller i Nes-skolen. Initiativet kom som følge av gjentatte nedslående resultater fra de internasjonale undersøkelsene PISA (OECD, 2003) og TIMSS (Grønmo, Bergem, Kjærnsli, Lie, \& Turmo, 2004). Prestasjonene til norske elever i naturfag og matematikk er nå under det gjennomsnittlige OECD-resultatet (Kjærnsli, Lie, Olsen, \& Roe, 2007). Tidligere har det blitt rapportert at elevene har et begrenset repertoar av læringsstrategier (Kjærnsli, Lie, Olsen, Roe, \& Turmo, 2004; Lie, Kjærnsli, Roe, \& Turmo, 2001). Som følge av funn i disse internasjonale unders $\varnothing$ kelsene har begrepet læringsstrategier fått aktualitet og blitt løftet frem som en mulig vei til bedre læring (Elstad \& Turmo, 2006). Den siste PISA-unders $\emptyset$ kelsen (Kjærnsli et al., 2007) gir bare svak støtte til at bedre oppøving av gode læringsstrategier vil fremme elevenes læring i faget. Hvordan læringsstrategier tilpasset situasjoner og fag vil kunne fremme læring, er noe av det vi vil studere nærmere i dette prosjektet.

I forbindelse med de internasjonale undersøkelsene har situasjonen i norsk skole blitt grundig analysert, og styrker og svakheter kartlagt. Det finnes derfor relativt god kunnskap om situasjonen sett fra et generelt nasjonalt ståsted, men vi mangler derimot forskningsbasert utviklingsarbeid som forsøker å videreutvikle og forbedre den pedagogiske praksisen i klasserommet. Dette prosjektet vil være et viktig bidrag i så måte. Nes kommune har opprettet samarbeid med forskere ved Høgskolen i Hedmark som vil lede prosjektet og gjennomføre utviklingsarbeidet og forskningen for bedre læringsstrategier i realfag. Det er også etablert samarbeid med det realfagdidaktiske miljøet ved University of Alberta, Canada. Provinsen Alberta er interessant fordi elevene der skorer blant de aller beste på PISA-testene (OECD, 2003, 2007), men også fordi det ser ut til at provinsen har utviklet en vellykket skolekultur og kommet langt når det for eksempel gjelder vurdering for læring, gjennom Alberta Assessment Consortium (2008). 


\section{DEN INNLEDENDE fASEN AV PROSJEKTET}

Et forskningsprosjekt der målet er å endre praksis bør innledes med en undersøkende og deskriptiv fase. Dette har skjedd våren og høsten 2007. Kartleggingen av skolekultur har foregått ved samtaler med lærere og ved klasseromsobservasjoner. Vi har også testet elevenes kunnskaper og utført både situasjonsspesifikke og generelle spørreundersøkelser om deres bruk av læringsstrategier. Hensikten med testene og spørreundersøkelsene har vært å kartlegge elevenes bevissthet om egne læringsstrategier, deres opplevde læringsutbytte og prestasjoner i realfag ved oppstart av prosjektet.

På bakgrunn av observasjoner av og samtaler med lærere og skoleledere om den nåværende praksis, er vi i ferd med å utvikle og gradvis innføre metoder som kan bidra til bedre læringsstrategier. Fra og med høsten 2007 har vi vært med i planleggingen av, observert og samlet inn data fra undervisningsopplegg ved de to skolene som er med i prosjektet. I denne innledende fasen av prosjektet har vi gjort nyttige erfaringer i forhold til samarbeidet med lærerne, rollefordelingen mellom lærer og forsker, hvordan teorier om læringsstrategier og metakognisjon (Bråten \& Olaussen, 1999; Weinstein, Bråten, \& Andreassen, 2006) kan omsettes til praksis i klasserommet og hvordan vi best kan fremskaffe empiri som gir oss relevant informasjon om det vi ønsker å undersøke. Gjennom dette innledende arbeidet høsten 2007 har forskningsspørsmålene utkrystallisert seg.

\section{MÅL OG FORSKNINGSSPФRSMÅL}

\section{Målene for prosjektet er:}

1. Lærere som formidler tydelige mål og vurderingskriterier til elevene

2. Elever som er selvregulerte i realfag

Dette innebærer:

- Elever som har et bredt repertoar av læringsstrategier i realfag

- Elever som har stor metakognitiv bevissthet om egen læring i realfag

- Realfagundervisning som oppleves som relevant og motiverende

3. Realfagsundervisning som preges av den utforskende metoden

I forhold til det første målet, stiller vi følgende forskningsspørsmål:

- Hvordan tar lærerne hensyn til og tolker kompetansemålene i naturfag i LK06?

- I hvilken grad er elevene bevisst målene med undervisningen?

- I hvilken grad er elevene kjent med og tar hensyn til vurderingskriteriene?

- Hvordan fører tydelige mål og vurderingskriterier til læring i realfag?

Videre stiller vi forskningsspørsmålene:

- Hvordan veileder læreren elevene i bruk av læringsstrategier?

- Hvilke læringsstrategier bruker elevene i ulike situasjoner i realfag, og hvorfor bruker de disse?

- Hvordan overvåker og kontrollerer elevene egen læring i realfag?

- Hva skjer med elevenes metakognitive bevissthet når undervisningen har tydelige mål og lærer veileder i bruk av læringsstrategier i realfag?

- Hvordan vil læringsstrategier tilpasset situasjoner og fag fremme læring?

At realfagundervisningen oppleves som relevant og motiverende og at undervisningen preges av den utforskende metoden er prinsipper som vi vil prøve å etterstrebe, men tid og kapasitet vil avgjøre om vi også vil forfølge dette i forskningen.

\section{UNDERVISNINGENS PRINSIPPER}

For å fremme metakognitiv bevissthet og hensiktsmessig bruk av læringsstrategier er det viktig at lærerne i prosjektet kommuniserer tydelige mål og vurderingskriterier til elevene. Hopfenbeck 
(2006) rapporterer i sin følgeforskning til PISA at det ser ut til å være en sammenheng mellom måten elever velger å bruke læringsstrategier på og måten læreren bruker vurderingskriterier på. Black \& William (1998) hevder at bruk av formativ vurdering i klasserommet er den aller mest effektive måten å forbedre elevenes læring på. Det er derfor naturlig og formålstjenelig å se læringsstrategier i nær sammenheng med formativ vurdering der tydelige vurderingskriterier kommuniseres til elevene.

Undervisningen skal videre ha metakognitivt preg, og det skal legges til rette for bruk av læringsstrategier som er situasjons- og fagspesifikke (for naturfagets del, skriving av laboratorierapport, trekke ut det viktigste av en naturfaglig tekst osv). I tillegg skal undervisningen være preget av den utforskende metoden i naturfag ("scientific inquiry"). Den utforskende metoden innebærer at elevene er aktive deltagere i læringsprosessen - som for eksempel i gruppesamtaler og ved bruk av forsøksmateriell, modeller og åpne aktiviteter. Hovedmålet er å la elevene bli kjent med undersøkelsesprosedyrer som brukes av forskere og å utvikle elevenes ferdigheter i å ta begrunnede avgjørelser (Barker, 2007). Beeth og Hewson (1999) studerte en lærer som lot elevene arbeide på en systematisk utforskende måte med naturfaglige fenomener. Lærer satte opp tydelige mål og kriterier som la til rette for en læringssituasjon som i stor grad lignet den som kjennetegner vitenskapelige miljøer. Like viktig var dialogen i etterkant om det de hadde undersøkt, ført i et språk som fremmet metakognisjon. De fant at elevene utviklet en metakognitiv bevissthet som var langt høyere enn det som man vanligvis forventer for den gitte aldersgruppen, og at elevene i stor grad ble selvregulerte. Disse funnene tyder på at den utforskende metoden, hvis den ledes på en god måte, fremmer metakognisjon og selvregulering hos elevene.

\section{FORSKNINGSMETODE}

Forskningstilnærmingen vil være interaktiv aksjonsforskning (Postholm, 2007). Møtet mellom forskere og deltagere er en dynamisk prosess. Forskeren fungerer som en prosessveileder. Det vil si at forskeren deltar aktivt i utformingen av forskningsopplegget, legger opp forskningsdesignet og skriver rapporter og drøfter funnene i forhold til teori (Carr \& Kemmis, 1986). Premissene som ligger til grunn for forskningsspørsmålene som blir stilt, har fremkommet etter en tett dialog mellom forskerne og skoleledere, lærere og foreldrerepresentanter i Nes kommune. Vi har hatt en felles studietur til Alberta i Canada, to workshops, besøk av forskere fra Universitetet i Alberta og en rekke møter med de involverte lærerne, skoleledere og foreldrerepresentanter.

\section{DATAIN NSAMLING}

I dette prosjektet vil det bli brukt både kvalitative og kvantitative metoder. For å måle effekten av endringene av praksis, når det gjelder bruk av læringsstrategier, vurderingskultur og oppnådd læring, vil det bli gjennomført kartlegging og innhentet data ved prosjektstart og kontinuerlig gjennom prosjektperioden. Datainnsamlingen vil foregå gjennom:

- Studier av skolens studie- og plandokumenter

- Klasseromsobservasjoner

Forsker vil være tilstede i klasserommet fire dager på hver av skolene i hvert semester. Forsker skal i størst mulig grad observere undervisningen.

- Elevlogg, egenvurdering og spørreundersøkelser

Gjennom prosjektperioden vil elevene levere inn skriftlige arbeider der spesifikke strategier er brukt. Elevene vil i tillegg svare på spørreskjemaer om deres bevissthet om mål og vurderingskriterier og spesifikke strategibruk. Her skal det brukes en enquete om strategibruk til elevene (tilpasset fra Cross-Curricular Competencies, CCC).

- Regelmessig testing av oppnådd læring i matematikk og naturfag (standardiserte og kvalitetssikrede prøver)

Det skal utarbeides tester både før og etter undervisning i gitte emner. Elevene skal også gjennomføre større kunnskapstester. 
- Samtaler og intervjuer med elever og lærerne i prosjektet:

I hver klasse skal vi ha en fokusgruppe på 3-4 elever som intervjues jevnlig gjennom forskningsperioden. Intervjuene vil fungere som en metode til å få utdypende svar i forhold til kunnskapstester, strategitester og elevlogger. I tillegg skal elevenes lærere intervjues.

Datainnsamlingen og den gradvise endringen av praksis vil være integrerte prosesser. Metode og praksis vil være i et kontinuerlig samspill.

\section{Deltagerskolene}

Forskningsarbeidet gjennomføres på 8. trinn (skoleåret 2007/2008) på Runni ungdomsskole og på 4. og 5. trinn (skoleåret 2007/2008) på Fjellfoten skole, begge i Nes kommune, Akershus. Vi vil gjennom en treårsperiode følge disse elevgruppene og deres lærere i naturfag og matematikk. Alle lærerne er kvinner. Lærerne på barneskolen er allmennlærere uten spesiell realfaglig bakgrunn, og lærerne på ungdomskolen har realfaglig bakgrunn i tillegg til pedagogisk utdannelse.

\section{REFERANSER}

Barker, S. (2007). Personlig kommunikasjon med Susan Barker, Universitetet i Alberta.

Beeth, M. E., \& Hewson, P. W. (1999). Learning goals in an exemplary science teacher's practice: Cognitive and social factors in. Science Education, 83(6), 738.

Black, P., \& Wiliam, D. (1998). Inside the Black Box: Raising standards through classroom assessment. Phi Delta Kappa, 80(2), 139-148.

Bråten, I., \& Olaussen, B. S. (1999). Strategisk loering : teori og pedagogisk anvendelse. Oslo: Cappelen akademisk forl.

Carr, W., \& Kemmis, S. (1986). Becoming critical : education, knowledge, and action research. London: Falmer Press.

Elstad, E., \& Turmo, A. (2006). Laringsstrategier : søkelys på lcerernes praksis. Oslo: Universitetsforl.

Grønmo, L. S., Bergem, O. K., Kjærnsli, M., Lie, S., \& Turmo, A. (2004). TIMSS 2003 med få ord. En kortversjon av den nasjonale rapporten: "Hva i all verden har skjedd i realfagene?" (Vol. 40). Oslo.

Hopfenbeck, T. N. (2006). The assessment of and for learning strategies. Sist sett 2007-12-20, 2007, fra http://northumbria.ac.uk/static/worddocuments/TheresHopfenbeck.doc

Kjærnsli, M., Lie, S., Olsen, R. V., \& Roe, A. (2007). Tid for tunge løft : norske elevers kompetanse $i$ naturfag, lesing og matematikk i PISA 2006. Oslo: Universitetsforlaget.

Kjærnsli, M., Lie, S., Olsen, R. V., Roe, A., \& Turmo, A. (2004). Rett spor eller ville veier? : norske elevers prestasjoner i matematikk, naturfag og lesing i PISA 2003. Oslo: Universitetsforl.

Lie, S., Kjærnsli, M., Roe, A., \& Turmo, A. (2001). Godt rustet for framtida? Norske 15-åringers kompetanse $i$ lesing og realfag $i$ et internasjonalt perspektiv. Oslo: Institutt for lærerutdanning og skoleutvikling, Universitetet i Oslo

OECD. (2003). The PISA 2003 assessment framework : mathematics, reading, science and problem solving knowledge and skills. [Paris]: OECD.

OECD. (2007). PISA 2006 : science competencies for tomorrow's world. Paris: OECD.

Postholm, M. B. (2007). Interaktiv aksjonsforskning : forskere og praktikere i gjensidig bytteforhold. I M. B. Postholm (red.), Forsk med! Loerere og forskere i laeringsarbeid (s. s. 12-33). Oslo: Damm.

Weinstein, C. E., Bråten, I., \& Andreassen, R. (2006). Læringsstrategier og selvregulert læring: teoretisk beskrivelse, kartlegging og undervisning. I E. Elstad \& A. Turmo (red.), Laeringsstrategier : søkelys på loerernes praksis (s. 28). Oslo: Universitetsforlaget.

AAC. (2008). Alberta Assessment Consortium. Sist sett 29. januar, 2008, fra http://www.aac. ab.ca/ 